\title{
PENGARUH MOTIVASI KERJA TERHADAP KINERJA PEGAWAI BADAN PENANGGULANGAN BENCANA DAERAH KABUPATEN MUSI BANYUASIN
}

\author{
Fery Supriyanto \\ Imelda \\ Sri Gustini \\ Sekolah Tinggi Ilmu Ekonomi Rahmaniyah Sekayu \\ Email : \\ ferisupriyanto@stier.ac.id \\ srigustini.mudrik@gmail.com
}

\begin{abstract}
This research entitled "The effect of work motivation towards job performance of Badan Penanggulangan Bencana Daerah employees of Musi Banyuasin Regency". Population in this research is 60 persons of Badan Penanggulangan Bencana Daerah employees of Musi Banyuasin regency. The sample of this research is all of BPBD employees Musi Banyuasin regency, so that this reaserch is called as population research, where all of population with the total number of 60 is as sample. Sampling technique that is used is using saturated sampling. The research findings showed that Motivation has impact towardsemployees' job performance of Badan Penanggulangan Bencana Daerah Musi Banyuasin regency. from the validity and reliability testresult by using SPSS is got if $r$ obtained value $\geq r$ table, motivation value is 0.610 and employees' job performance value is 0.616 so this value is higher than $r$ critical value of product moment that is 0.254 (look at appendices of $r$ table).Constants is 6.218 , regression coeffisient of motivation variable $(X)$ is 0.851 . Based on t-test value ia got that t-obtained value is higher than $t$-table value (14.569 $>2.002)$.
\end{abstract}

Keywords: job motivation, job performance

\section{PENDAHULUAN}

\section{Latar Belakang Masalah}

Badan Penanggulangan Bencana Daerah Kabupaten Musi Banyuasin merupakan instansi yang bergerak pada bidang penanggulangan bencana. Dalam pekerjaan ini para pegawai dituntut untuk dapat bekerja secara professional, oleh karena itu dalam suatu organisasi perlu adanya fungsi pengarahan yang diperlukan dalam rangka mendorong kineja para pegawai. Guna tercapainya hal tersebut perlu adanya motivasi yang diharapkan dapat meningkatkan kinerja pegawai.

Motivasi terbentuk dari sikap karyawan dalam menghadapi situasi kerja di perusahaan atau organisasi. Motivasi merupakan kondisi atau energi yang menggerakkan diri 
karyawan atau pegawai yang terarah atau tertuju untuk mencapai tujuan organisasi perusahaan. Sikap yang pro dan positif terhadap situasi kerja itulah yang memperkuat motivasi kerjanya untuk mencapai kinerja maksimal. Menurut Wahjosumidjo (2011: 201), motivasi adalah pertemuan antara pengaruh internal dan pengaruh external. Motivasi karyawan berarti memberi dorongan kepada karyawan sehingga mau bekerja dengan baik dan dapat memberikan hasil maksimal pada perusaan.

Guna mewujudkan kinerja pegawai tersebut seorang pemimpin harus dapat memberikan perhatian. Hal ini berarti bahwa motivasi tidak hanya sebatas aspek materil tetapi juga harus didukung dengan aspek nonmaterial juga sehingga pegawai dapat bekerja dengan baik dan pegawai merasa puas serta hasil kerjanya dihargai. Dengan demikian motivasi yang dilakukan oleh seorang pimpinan ini diharapkan menimbulkan dorongan dari dalam diri pegawai itu sendiri untuk melakukan tugas-tugas yang telah diberikan dan ini akan menimbulkan adanya rasa tanggung jawab yang besar sehingga dapat berdampak pada tingkat kreativitas pegawai. Kinerja pegawai merupakan suatu hasil kesuksesan yang dicapai oleh suatu organisasi dalam pekerjaannya.

Kinerja pegawai dapat diukur dengan menilai hasil yang dicapai, tingkah laku yang ditampilkan berdasarkan dengan tugasnya. Kinerja itu dimulai dari tingkat pencapaian target, inisiatif, loyalitas dan kerja sama yang baik dalam kelompok, disiplin, kesadaran akan pengembangan diri untuk meningkatkan pengetahuan.

Menurut hasil analisa dan hasil wawancara sementara diperoleh informasi bahwa Badan Penanggulangan Bencana Daerah ini belum mempunyai cara untuk motivasi yang baik. Hal ini terlihat dari tunjangan dan bonus yang diberikan belum sesuai dengan hasil kerja para pegawai serta cara memperlakukan para pegawai pun belum berjalan baik seperti menurut McCelland (2011:26), produktivitas seseorang ditentukan oleh "virus mental" yang ada pada dirinya. Virus mental yang dimaksud terdiri dari 3 dorongan kebutuhan, yaitu : kebutuhan berprestasi, kebutuhan untuk memperluas pergaulan dan kebutuhan untuk menguasi sesuatu. Hal ini memberikan dampak masih ada pegawai yang dalam menjalankan tugasnya kurang disiplin dan malas-malasan sehingga secara kontra diktif kinerja karyawan masih relative rendah.

Tabel 1

Data kinerja BPBD Pada

Siaga Api dan Asap Tahun 2014 dan 2015

\begin{tabular}{|c|c|c|}
\hline Tahun & Data Api (Titik Api) & Keterangan \\
\hline 2014 & 257 & 34 titik api ditemukan padam \\
\hline 2015 & 314 & 56 titik api ditemukan padam \\
\hline
\end{tabular}

Sumber : BPBD Kab. Musi Banyuasin Tahun 2014 dan 2015

Berdasarkan fenomena diatas, maka penulis tertarik untuk mengadakan penelitian dengan judul "Pengaruh Motivasi Kerja Terhadap Kinerja Pegawai BPBD Kabupaten Musi Banyuasin"

\section{Rumusan Masalah}

Rumusan masalah dalam penelitian ini adalah "Seberapa Besar Pengaruh Motivasi Terhadap Kinerja Pegawai pada Kantor Badan Penanggulangan Bencana Daerah Kabupaten Musi Banyuasin?".

\section{Tujuan Penelitian}

Desember 2018

JURNAL MANAJEMEN KOMPETEN 
Adapun tujuan dari penelitian ini adalah untuk mengetahui seberapa besar Pengaruh Motivasi Kerja Terhadap Kinerja Pegawai BPBD Kabupaten Musi Banyuasin.

\section{KAJIAN PUSTAKA \\ Pengertian Kinerja}

Kinerja merupakan perwujudan kerja yang dilakukan oleh pegawai yang biasanya dipakai sebagai dasar penilaian terhadap pegawai atau individu. Menurut Rivai (2010: 309), mengemukakan bahwa "Kinerja menyatakan perilaku nyata yang ditampilkan setiap orang sebagai prestasi kerja yang dihasilkan oleh pegawai sebagai peranannya dalam perusahaan. Kinerja pegawai merupakan suatu hal yang sangat penting dalam upaya perusahaan untuk mencapai tujuannya".

Menurut Hasibuan (2012: 108) "Kinerja adalah suatu hasil kerja yang dicapai seseorang dalam melaksanakan tugas-tugas yang dibebankan kepadanya yang didasarkan atas kecakapan, pengalaman dan kesungguhan serta waktu". Menurut Mangkunegara (2010: 108) "Kinerja adalah prestasi baik atau kualitas maupun kuantitas yang dicapai sumber daya manusia persatuan periode waktu dalam melaksanakan tugas kerjanya sesuai dengan tanggung jawab yang diberikan kepadanya".

\section{Pengukuran Kinerja}

Ukuran bagian-bagian mana yang dianggap penting dalam suatu pekrjaan memang sulit untuk ditetapkan karena berbagai jenis pekerjaan yang beragam yang mempunyai ukuran yang berbeda. Untuk pengukuran kinerja seorang karyawan selalu meperhatikan dan mempertimbangkan masalah kuantitas pekerjaan , kualitas dan ketetapan kerja.

a. Kuantitas

Kuantitas merupakan jumlah pekerjaan yang dihasilkan oleh pegawai dalam ukuran waktu tertentu berdasarkan standar kerja yang ditetapkan.

b. Kualitas

Kualitas merupakan ketelitian, keterampilan dan kesesuaian dari hasil pekerjaan yang dilakukan oleh seseorang dalam kurun waktu tertentu berdasarkan standar kerja yang ditetapkan.

c. Ketetapan Kerja

Ketetapkan kerja merupakan kemampuan seorang pegawai dalam mengerjakan dan menyelesaikan tugas yang menjadi tanggung jawabnya sesuai dengan jangka waktu yang ditentukan.

\section{Faktor-Faktor yang Mempengaruhi Kinerja}

Menurut Mangkunegara (2011: 67) ada dua faktor yang memepngaruhi pencapaian kenirja yaitu :

a. Faktor Kemampuan (ability), secara individu kemampuan terdiri dari kemampuan potensial dan kemampuan reality.

b. Faktor Motivasi (motivation), suatu sikap pimpinan dan pegawai terhadap situasi kerja dilingkungan individu.

\section{Konsep Motivasi}

Motivasi berasal dari kata latin movere yang berarti dorongan atau mengerakan. Motivasi dalam manajemen hanya ditujukan pada sumber daya manusia pada umumnya dan bawahan khususnya. Motivasi mempersoalkan bagaimana caranya mengarahkan daya dan 
potensi bawahan agar mau bekerja sama secara produktif berhasil mencapai dan mewujudkan tujuan yang telah ditentukan.

Menurut Handoko (2011: 9) "Motivasi adalah suatu tenaga atau faktor-faktor yang terdapat dalam diri manusia yang menimbulkan, mengarahkan dan mengorganisasikan tingkah lakunya". Sedangkan menurut Hasibuan (2011: 143) "Motivasi adalah pemberian gaya penggerak yang menciptakan kegairahan kerja seseorang agar mereka mau bekerja sama, bekerja efektif dan terintegrasi dengan segala daya upayanya untuk mencapai kepuasan".

Jadi motivasi adalah sesuatu yang menimbulkan dorongan atau semangat kerja. Secara singkat motivasi dapat diartikan sebagai bagian integral, hubungan dalam pembinaan, pengembangan dan pengarahan sumber daya manusia. Berdasarkan pandangan diatas motivasi dirumuskan sebagai berikut : (1) Setiap perasaan atau kehendak dan keinginan yang sangat mempengaruhi kemauan individu sehingga individu tersebut didorong untuk berperilaku dan bertindak. (2) Setiap tindakan atau kejadian yang menyebabkan berubahnya perilaku seseorang. (3) Pengaruh kekuatan yang menimbulkan perilaku individu dan proses menentukan gerakan perilaku individu kepada tujuan.

Menurut Hasibuan (2011: 149) Motivasi dibagi menjadi dua yaitu :

1. Motivasi Langsung (Direct Motivation)

Motivasi langsung adalah motivasi (materiil dan non materiil) yang deiberikan secara langsung kepada setiap individu pegawai untuk memenuhi kebutuhan serta kepuasannya. Misalnya : Gaji, bonus, komisi, tunjangan dan penghargaan.

a. Gaji

Gaji adalah suatu bentuk balas jasa ataupun penghargaan yang diberikan secara teratur kepada seorang pegawai atas jasa dan hasil kerjanya.

b. Bonus

Bonus adalah uang yang dibayarkan sebagai balas jasa atau hasil pekerjaan yang telah dilaksanakan, dihitung berdasarkan presentase dari laba perusahaan yang melebihi jumlah tertentu dan dimasukkan kedalam dana bonus kemudian dibagi kepada pimpinan dan pegawai, tidak ada aturan yang pasti mengenai pemberian bonus, tergantung pada kebijakan masing-masing perusahaan.

c. Komisi

Komisi merupakan suatu jenis insentif yang dibayar kepada pihak yang menghasilkan target kinerja ang terbaik.

d. Tunjangan

Tujangan adalah unsur-unsur balas jasa yang diberikan dalam nilai rupiah secara langsung kepada pegawai individual dan dapat diketahui secara pasti. Tujangan diberikan kepada pegawai dimaksud agar dapat menimbulkan/meningkatkan semangat kerja dan kegairahan bagi pegawai.

e. Penghargaan

Penghargaan adalah balas jasa yang diberikan oleh perusahaan kepada para pegawainya berupa pengakuan atas hasil kerja baik secara lisan maupun tulisan.

2. Motivasi Tak Langsung (Inderect Motivation)

Motivasi tak langsung adalah motivasi yang diberikan hanya merupakan fasilitasfasilitas yang mendukung serta menunjang gairah kerja/kelancaran tugas sehingga para pegawai betah dan bersemangat melakukan pekerjaannya. Misalnya : kursi yang empuk, mesin-mesin yang baik, ruangan kerja yang terang dan nyaman, suasana pekerjaan yang serasi serta penempatan yang tepat.

Desember 2018

JURNAL MANAJEMEN KOMPETEN 
a. Lingkungan kerja

1. Lingkungan Eksterior

Merupakan lingkungan atau penampilan luar dari sebuah perusahaan yang dapat menarik perhatian pengunjung.

2. Desain Ekterior

Eksterior sering dikaitkan dengan seni atau keindahan, dimana eksterior adalah cerminan awal dari pengunjung dalam dalam beraktifitas pada sebuah perusahaan/kantor. Eksterior memiliki peran yang sangat penting untuk menimbulkan kesan nyaman bagi karyawan maupun pengunjung dalam beraktifitas.

b. Tata Ruang

Tata ruang mengacu pada cara-cara penyusunan mesin-mesin, peralatan, perabotan sesuai ukuran, bentuk dan fungsinya untuk memfasilitasi tercapainya tujuan pegawai.

c. Penerangan

Berdasarkan penelitian, cahaya lampu yang tidak memadai akan berpengaruh negatif terhadap keterampilan kerja. Dalam melaksanakan tugas seringkali pegawai membutuhkan penerangan yang cukup, apalagi bila pekerjaan yang dilakukan tersebut memiiki ketelitian. Penerangan atau cahaya lampu harus pula disesuaikan dengan ukuran ruangan kerja serta kondisi mata pegawai. Penerangan memiliki manfaat yang sangat besar bagi pegawai yaitu untuk proses kelancaran kerja. Oleh sebab itu perlu diperhatikan adanya penerangan atau cahaya yang cukup terang dan tidak menyilaukan mata.

Berdasarkan pemaparan diatas bahwa seorang pemimpin dalam suatu perusahaan/kantor harus dapat memotivasi pegawainya tidak hanya dari aspek materiil maupun non materiil, tetapi juga harus memperhatikan motivasi tidak langsung yang berkaitan dengan fasilitas dan lingkungan dalam bekerja.

\section{Teori Motivasi}

1. Jenis-jenis Teori Motivasi

Menurut Hasibuan (2011: 152) teori-teori motivasi dikelompokan atas tiga macam :

a. Teori Kepuasan

Teori kepuasan mendasarkan pendekatannya atas faktor-faktor kebutuhan dan kepuasan individu yang menyebabkannya bertindak serta berperilaku dengan cara tertentu. Teori ini memusatkan perhatian pada faktor-faktor dalam diri orang yang menguatkan, mengarahkan, mendukung dan menghentikan perilakunya. Teori ini mencoba menjawab pertanyaan kebutuhan apa yang memuaskan seseorang dan apa yang mendorong semangat bekerja seseorang.

b Teori Motivasi Proses

Teori motivasi proses pada dasarnya berusaha menjawab pertanyaan bagaimana menguatkan, mengarahkan, memelihara dan menghentikan perilaku individu bekerja sesuai dengan keinginan pimpinan. apabila diperhatikan secara mendalam teori ini merupakan proses sebab dan akibat bagaiman seseorang bekerja serta hasil yang akan diperolehnya. Jika bekerja baik saat ini, hasilnya akan diperoleh baik untuk hari esok. jadi hasilnya akan dicapai tercermin pada bagaimana proses kegiatan yang dilakukan seseorang.

c. Teori Pengukuhan

Teori ini didasarkan atas hubungan sebab akibat dari perilaku dengan pemberian kompensasi. Misalnya : Bonus kelompok tergantung pada tingkat produksi kelompok.

2. Teori Motivasi Menurut Para Ahli

Menurut Abraham Maslow "Seseorang berperilaku/bekerja karena adanya dorongan untuk memenuhi berbagai macam kebutuhan, kebutuhan yang diinginkan seseorang itu berjenjang". Artinya jika kebutuhan yang pertama telah terpenuhi maka kebutuhan tingkat 
kedua akan muncul menjadi yang utama. Selanjutnya jika kebutuhan tingkat kedua telah terpenuhi, muncul kebutuhan tingkat ketiga dan seterusnya sampai tingkat kebutuhan kelima.

Gambar hierarki kebutuhan menurut Abraham Maslow adalah sebagai berikut :

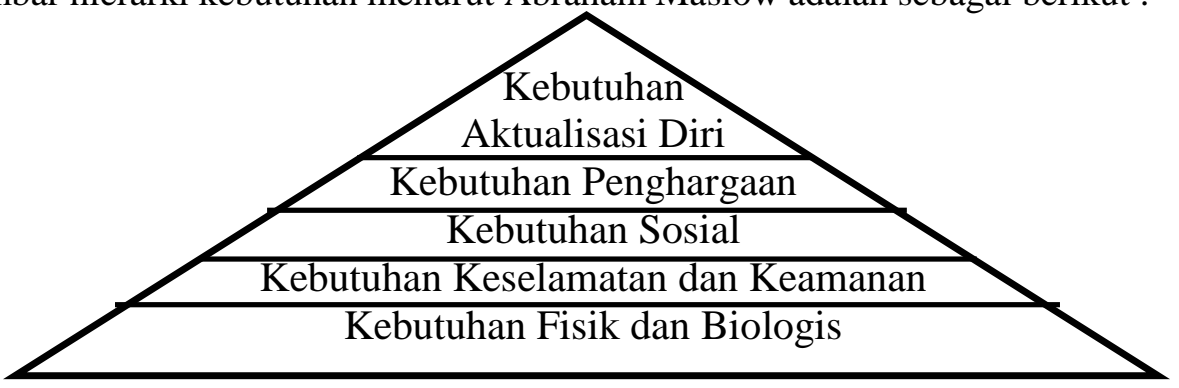

Gambar 1

Hierarki Kebutuhan Menurut Abraham Maslow

a. Kebutuhan Fisik dan Biologis

yaitu kebutuhan untuk mempertahankan hidup. Yang termasuk dalam kebutuhan ini adalah kebutuhan makanan, minum, perumahan, udara dan sebagainya.

b. Kebutuhan Keselamatan dan Keamanan

adalah kebutuhan akan kebebasan dari ancaman yakni merasa aman dari ancaman kecelakaan dan keselamatan dalam melaksanakan pekerjaan.

c. Kebutuhan Sosial

adalah kebutuhan social, teman, afiliasi, interaksi, dicintai dan mencintai serta diterima dalam pergaulan kelmpok pekerja dan masyarakat lingkungannya.

d. Kebutuhan Akan Penghargaan atau Apresiasi

adalah kebutuhan akan penghargaan diri dan pengakuan serta penghargaan prestasi dari pegawai dan masyarakat lingkungannya.

e. Aktualisasi Diri

adalah kebutuhan akan aktualisasi diri dengan menggunakan kemampuan, keterampilan, dan potensi optimal untuk mencapai prestasi kerja yang sangat memuaskan/luar biasa.

\section{Kerangka Pemikiran}

Untuk mempermudah dalam penyusunan skripsi ini penulis menyusun kerangka pemikiran sebagai berikut :

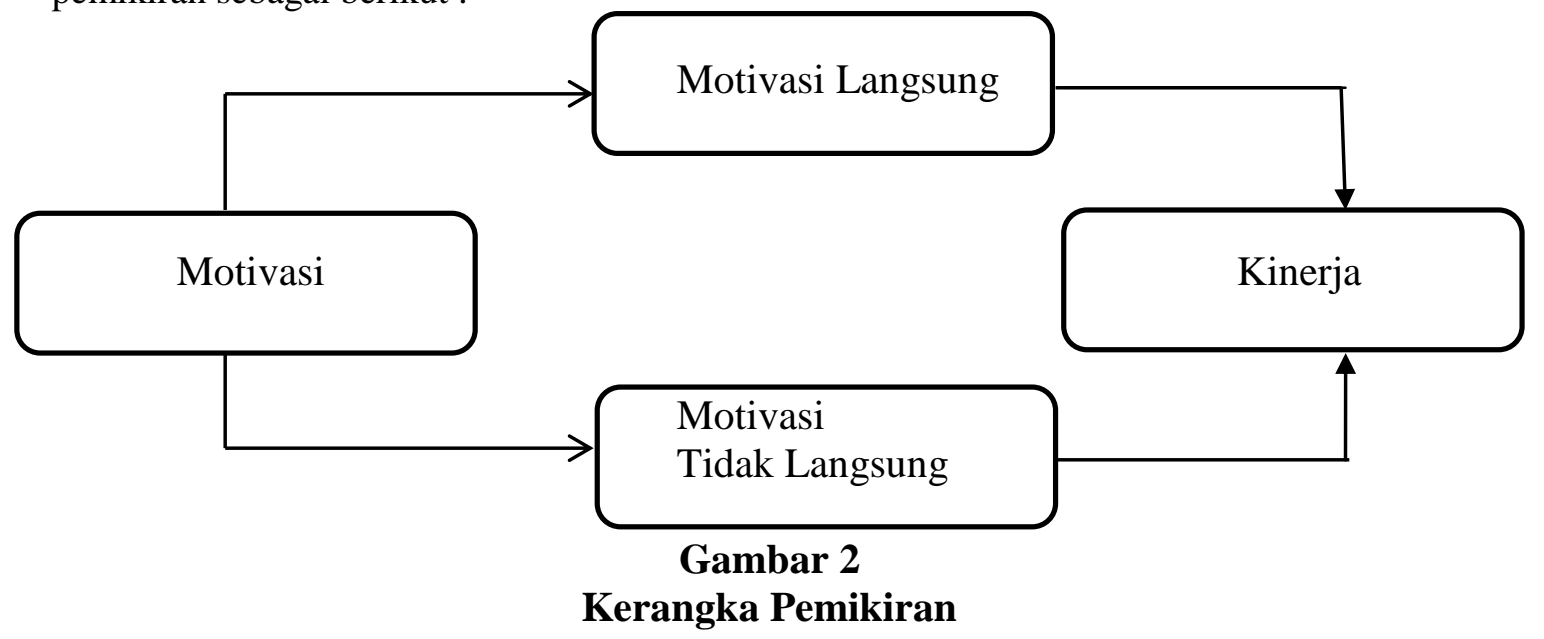

Desember 2018

JURNAL MANAJEMEN KOMPETEN 
Berdasarkan gambar diatas, maka dapat dilihat bahwa, motivasi adalah pemberian gaya penggerak yang menciptakan kegairahan kerja seseorang agar mereka mau bekerja sama, bekerja efektif dan terintegrasi dengan segala daya upayanya untuk mencapainya kepuasan. Untuk menumbuhkan motivasi kerja karyawan perlu adanya motivasi secara langsung maupun tidak langsung. Motivasi langsung dan tidak langsung berpengaruh pada kinerja pegawai. Kurangnya motivasi maka kinerja karyawan akan menurun.

\section{Hipotesis Penelitian}

Diduga motivasi kerja diberikan secara langsung dan tidak langsung akan berpengaruh positif terhadap kinerja pegawai BPBD Kabupaten Musi Banyuasin.

\section{METODE PENELITIAN}

\section{Populasi, Sampel dan Teknik Pengambilan Sampel}

Menurut Sanusi (2011: 87) `Populasi adalah elemen yang menunjukkan ciri-ciri tertentu yang digunakan untuk membuat kesimpulan. Yang menjadi populasi dalam penelitian ini adalah pegawai Badan Penanggulangan Bencana Daerah Kabupaten Musi Banyuasin Yang berjumlah 60 orang. Sedangkan sampel adalah bagian dari elemen-elemen populasi yang dipilih. Yang menjadi sampel dalam penelitian ini adalah seluruh pegawai BPBD Kabupaten Musi Banyuasin, sehingga penelitian ini deisebut juga sebagai penelitian populasi, dimana jumlah populasi sebanyak 60 orang dijadikan sebagai sampel.

\section{Jenis dan Sumber Data}

Menurut Sanusi (2011: 104) data yang digunakan dalam penelitian ini ada dua jenis:

a. Data primer adalah data pertamakali dicatat dan dikumpulkan oleh peneliti (misalnya : responden individu, kelompok, fokus, internet dll)". Data primer dalam penelitian ini penulis dapatkan dari hasil wawancara dengan pimpinan dan karyawan tentang motivasi yang diberikan.

b. Data sekunder adalah data yang sudah tersedia dan dikumpulkan oleh pihak lain (misalnya : dokumentasi perusahaan, pemerintah, publikasi, analisis industry oleh media, situs web, internet dll)". Adapun data sekunder dalam penelitian ini adalah tentang keadaan umum Badan Penanggulanngan Bencana Daerah Kabupaten Musi Banyuasin data kehadiran karyawan.

\section{Instrumen Penelitian}

Dalam penulisan skripsi ini instrument penelitian yang penulis gunakan adalah kuesioner dengan pengukuran menggunakan skala likert. Menurut Sanusi (2011: 109) Kuesioner adalah pengumpulan data sering tidak memerlukan kehadiran peneliti namun cukup diwakili oleh daftar pertanyaan yang disusunn secara cermat terdahulu. Sedangkan skala likert Menurut Sanusi (2011: 59) adalah skala yang didasarkan pada penjumlahan sikap responden dalam merespon pertanyaan berkaitan indikator-indikator suatu konsep atau variabel yang sedang diukur dengan batasan sebagai berikut :

$\begin{array}{ll}\text { SS (Sangat Setuju) } & =5 \\ \text { S (Setuju) } & =4 \\ \text { RG (Ragu-Ragu) } & =3 \\ \text { TS (Tidak Setuju) } & =2 \\ \text { STS (Sangat Tidak Setuju) } & =1\end{array}$




\section{Definisi Operasionalisasi Variabel}

Data yang terkumpul berupa isian kuesioner dari pegawai atas variabel-variabel yang diteliti seperti terlihat pada tabel operasionalisasi berikut ini :

Tabel 2

Definisi Operasionalisasi Variabel

\begin{tabular}{|c|c|c|c|c|}
\hline No. & Variabel & Dimensi & Indikator & $\begin{array}{c}\text { Item } \\
\text { Pertanyaan }\end{array}$ \\
\hline \multirow[t]{2}{*}{1.} & \multirow[t]{2}{*}{$\begin{array}{c}\text { Variabel X } \\
\text { (motivasi) } \\
\text { adalah variabel bebas }\end{array}$} & $\begin{array}{l}\text { 1. Motivasi } \\
\text { Langsung }\end{array}$ & $\begin{array}{l}\text { 1. Gaji yang memadai. } \\
\text { 2. Pemberian Bonus. } \\
\text { 3. Pemberian Komisi. } \\
\text { 4. Tunjangan-tunjangan. } \\
\text { 5. Penghargaan non } \\
\text { materiil. }\end{array}$ & 1 s.d 5 \\
\hline & & $\begin{array}{l}\text { 2. Motivasi } \\
\text { Tidak } \\
\text { Langsung }\end{array}$ & $\begin{array}{l}\text { 1. Ruangan Kerja yang } \\
\text { terang dan nyaman. } \\
\text { 2. Mesin-mesin yang baik. } \\
\text { 3. Suasana kerja yang } \\
\text { serasi. }\end{array}$ & $\begin{array}{l}6 \text { s.d } 7 \\
8 \text { s.d } 9 \\
10\end{array}$ \\
\hline \multirow[t]{3}{*}{2.} & \multirow{3}{*}{$\begin{array}{c}\text { Variabel Y } \\
\text { (kinerja) } \\
\text { Adalah variabel } \\
\text { terikat }\end{array}$} & \multirow{3}{*}{$\begin{array}{l}\text { Kinerja } \\
\text { Pegawai }\end{array}$} & 1. Kuantitas. & 1 s.d 3 \\
\hline & & & 2. Kualitas. & 4 s.d 6 \\
\hline & & & 3. Ketepatan Kerja. & 7 s.d 10 \\
\hline
\end{tabular}

Sumber : Penulis 2016

Berdasarkan tabel diatas dapat dilihat bahwa variabel motivasi (X) terbagi menjadi dua yaitu motivasi langsung dan motivasi tidak langsung, setiap motivasi tersebut memiliki indikator-indikator masing-masing yang dijadikan sebagai item pertanyaan didalam kuesioner yang disesuaikan dengan urutan nomor item pertanyaan tersebut. Selain darai pada itu variable kinerja pegawai (Y) juga memiliki indikator-indikator nya masing-masing yang dijadikan sebagai item pertanyaan didalam kuesioner yang telah disesuaikan dengan urutan nomor item pertanyaan tersebut.

\section{Teknik Pengumpulan Data}

Teknik pengumpulan data yang dilakukan penulis pada penulisan skripsi ini adalah :

1. Wawancara adalah teknik pengumpulan data yang digunakan penulis dengan berkomunikasi langsung dengan responden.

2. Dokumentasi adalah pengumpulan data dari catatan tertulis tentang berbagai kegiatan atau peristiwa pada masa lalu.

3. Studi Kepustakaan adalah segala usaha yang dilakukan oleh peneliti untuk menghimpun informasi yang relevan dengan topik atau masalah yang akan atau sedang diteliti.

4. Kuesioner adalah seperangkat pertanyaan yang diberikan secara langsung kepada resonden untuk diisi.

\section{Teknik Analisis Data} Uji Validitas 
Menurut Priyatno (2010: 16) "Uji validitas adalah ketepatan dan kecermatan suatu instrument dalam mengukur apa yang ingin diukur". Uji ini dengan cara mengorelasikan masing-masing skor item dengan skor total. Skor total adalah penjumlahan dari keseluruhan item. Item-item pertanyaan yang berkorelasi signifikan dengan skor total menunjukan itemitem tersebut mampu memberikan dukungan dalam mengungkap apa yang ingin diungkap. Rumus yang digunakan adalah sebagai berikut:

$$
r_{i x}=\frac{\mathrm{n} \sum \mathrm{ix}-\left(\sum \mathrm{i}\right)\left(\sum \mathrm{x}\right)}{\sqrt{\left[\mathrm{n} \sum \mathrm{i}^{2}-\left(\sum \mathrm{i}\right)^{2}\right]\left[\mathrm{n} \sum \mathrm{x}^{2}-\left(\sum \mathrm{x}\right)^{2}\right]}}
$$

Keterangan :

$\mathrm{r}_{\mathrm{ix}}=$ Koefesien korelasi item-total.

$\mathrm{i}=$ Skor item (Banyaknya Sampel).

$\mathrm{x}=$ Skor Total (Variabel Bebas).

$\mathrm{n}$ = Banyaknya Subjek (Variabel Terikat).

Pengujian menggunakan uji dua sisi dengan taraf signifikasi 0,05. Kriteria pengujian adalah sebagai berikut :

- Jika $\mathrm{r}$ hitung $\geq \mathrm{r}$ table (uji 2 sisi dengan sig. 0,05) maka instrument atau item-item pertanyaan berkorelasi signifikan terhadap skor total (dinyatakan valid).

- Jika $r$ hitung < $r$ tabel (uji 2 sisi dengan sig. 0,05) maka instrument atau item-item pertanyaan tidak berkorelasi signifikan terhadap skor total (dinyatakan tidak valid).

\section{Uji Reliabilitas}

Menurut Priyatno (2010: 25) "Uji reliabitas digunakan untuk mengetahui konsistensi alat ukur, apakah alat pengukur yang digunakan dapat diandalkan dan tetap konsisten jika pengukuran tersebut diulang". Rumus reliabilitas dengan metode alpha adalah sebagai berikut

$$
\left.r_{11}=\frac{k}{k-1}[1] \frac{\sum \overline{\sigma b^{2}}}{\sigma 1^{2}}\right]
$$

Keterangan :

$\mathrm{r}_{11}=$ Reliabilitas instrumen

$\mathrm{k} \quad=$ Banyakna butir pertanyaan

$\sum \sigma b^{2}=$ Jumlah varian butir

$\sigma 1^{2}=$ Varian total

Uji signifikasi dilakukan pada taraf signifikasi0,05, artinya instrument dapat dikatan reliabel bila nilai alpha lebih besar dari $\mathrm{r}$ kritis product moment. Atau bisa menggunakan batasan batasan tertentu0,6. Realibitas kurang dari 0,6 adalah kurang baik, sedangkan 0,7 dapat diterima dan diatas 0,8 adalah baik.

\section{Analisis Regresi Linier Sederhana}

Menurut Priyatno (2010: 66) "Analisis regresi linier sederhana adalah hubungan secara linier antara satu variabel independen $(\mathrm{X})$ dengan variable dependen $(\mathrm{Y})$ ". Analisis ini untuk mengetahui arah hubungan antara variabel independen dengan variabel dependen apabila nilai variabel independen mengalami kenaikan atau penurunan. Data yang digunakan biasanya berskala interval atau rasio. Rumus regresi linier sederhana adalah sebagai berikut :

Keterangan :

$$
Y^{\prime}=a+b X
$$


$\mathrm{Y}^{\prime}=$ Variabel dependen (nilai yang diprediksi)

$\mathrm{X}=$ Variabel independen

a $=$ Konstanta (nilai Y apabila $\mathrm{X}=0$ )

$\mathrm{b}=$ Koefesien regresi (nilai peningkatan ataupun penurunan)

\section{Analisis Korelasi Sederhana}

$$
r_{x y}=\frac{n\left(\sum X Y\right)-\left(\sum X\right)\left(\sum Y\right)}{\sqrt{\left[n \sum X^{2}-\left(\sum X\right)^{2}\right]\left[\sum Y^{2}-\left(\sum Y\right)^{2}\right]}}
$$

Keterangan :

$\mathrm{n}=$ Jumlah Data

$\mathrm{X}=$ Variabel Pertama (variabel Bebas)

$\mathrm{Y}=$ Variabel Kedua (variabel terikat)

\section{Uji t}

Menurut Priyatno (2010: 70) "Uji ini digunakan untuk mengetahui apakah variabel independen (X) berpengaruh secara signifikan terhadap variabel dependen (Y). Signifikan berarti pengaruh yang terjadi dapat berlaku untuk populasi (dapat digeneralisasikan)".

\section{Dimana :}

- Ho : Tidak ada pengaruh secara signifikan antara motivasi terhadap kinerja pegawai.

- Ha : Ada pengaruh secara signifikan antara motivasi terhadap kinerja pegawai.

Kriteria Pengujian :

- Ho diterima jika $\mathrm{t}$ hitung $\leq \mathrm{t}$ tabel

- Ho ditolak jika t hitung $>\mathrm{t}$ tabel

\section{HASIL DAN PEMBAHASAN}

\section{Gambaran Umum Responden}

Informasi mengenai usia responden sangat penting untuk diketahui karena perbedaan umur masing-masing resonden dapat sangat berpengaruh terhadap sikap dan cara pandangnya dalam menilai pengaruh motivasi terhadap kinerja pegawai.

\section{Tabel 3}

Kategori Usia Responden

\begin{tabular}{|c|c|}
\hline Usia (Tahun) & Jumlah (Orang) \\
\hline $18-25$ & 15 \\
\hline $26-30$ & 10 \\
\hline $31-35$ & 8 \\
\hline $36-40$ & 9 \\
\hline $41-45$ & 8 \\
\hline $46-50$ & 7 \\
\hline$>50$ & 3 \\
\hline Total & $\mathbf{6 0}$ \\
\hline
\end{tabular}

Sumber : Data primer yang diolah 2017

Tabel diatas menunjukkan bahwa sebagian besar responden berusia muda, responden berusia 18-25 tahun berjumlah 15 orang, yang diikuti oleh responden yang berusia 
26-30 tahun berjumlah 10 orang, responden yang berusia 31-35 tahun berjumlah 8 orang, yang diikuti oleh responden 36-40 tahun 9 orang, responden yang berusia 46-50 tahun berjumlah 7 orang dan responden yang berusia diatas 50 tahun berjumlah 3 orang.

Tabel 4

Masa Bekerja Responden

\begin{tabular}{|c|c|}
\hline Lama Bekerja (Tahun) & Jumlah (Orang) \\
\hline$<2$ & 8 \\
\hline $3-5$ & 23 \\
\hline $6-15$ & 20 \\
\hline$>15$ & 10 \\
\hline Total & $\mathbf{6 0}$ \\
\hline
\end{tabular}

Sumber : Data primer yang diolah 2014

Berdasarkan tabel diatas menunjukkan bahwa responden yang memiliki masa bekerja $<2$ tahun sebanyak 8 orang, diikuti oleh responden yang memiliki masa bekerja 3-5 tahun sebanyak 23 orang, yang memiliki masa kerja 6-15 tahun sebanyak 20 orang serta terdapat 10 orang responden yang memiliki masa kerja lebih dari 15 tahun.

Tabel 5

Pendidikan Terakhir Responden

\begin{tabular}{|c|c|}
\hline Pendidikan & Jumlah (Orang) \\
\hline S2 & 10 \\
\hline S1 & 20 \\
\hline D3 & 0 \\
\hline SLTA/Sederajat & 30 \\
\hline Total & $\mathbf{6 0}$ \\
\hline
\end{tabular}

Sumber : Data primer yang diolah 2017

Berdasarkan tabel diatas menunjukkan bahwa responden yang memiliki pendidikan terakhir S3 sebanyak 10 Orang, S1 sebanyak 20 Orang dan D3 tidak ada, serta pegawai yang berpendidikan terakhir SLTA/ Sederajat berjumlah 30 Orang.

\section{Rekapitulasi Kuesioner}

Tabel 6

Distribusi Variabel Motivasi Langsung (X)

\begin{tabular}{|c|c|c|c|c|c|c|}
\hline \multirow{2}{*}{ Item } & \multicolumn{7}{|c|}{ Responden } & \multirow{2}{*}{$\begin{array}{c}\text { Jumlah } \\
\text { Responden }\end{array}$} \\
\cline { 2 - 6 } & SS & S & RG & TS & STS & 60 \\
\hline 1 & 26 & 25 & 7 & 1 & 1 & 60 \\
\hline 2 & 29 & 26 & 5 & 0 & 0 & 60 \\
\hline 3 & 29 & 27 & 3 & 1 & 0 & 60 \\
\hline 4 & 30 & 22 & 8 & 0 & 0 & 60 \\
\hline 5 & 31 & 17 & 10 & 2 & 0 & 60 \\
\hline 6 & 22 & 29 & 8 & 1 & 0 & 60 \\
\hline 7 & 29 & 22 & 7 & 1 & 1 & 60 \\
\hline 8 & 26 & 25 & 5 & 1 & 3 & 60 \\
\hline 9 & 25 & 20 & 10 & 3 & 2 & 60 \\
\hline 10 & 13 & 12 & 4 & 1 & 0 & \\
\hline
\end{tabular}


Berdasarkan tabel diatas menunjukkan bahwa untuk item 1 responden yang menjawab sangat setuju sebanyak 26 orang, setuju sebanyak 25 orang, ragu-ragu sebanyak 7 orang, tidak setuju sebanyak 1 orang dan sangat tidak setuju sebanyak 1 orang. Untuk item 2 responden yang menjawab sangat setuju sebanyak 22 orang, setuju sebanyak 25 orang, raguragu sebanyak 11 orang dan responden yang menjawab tidak setuju sebanyak 2 orang serta sangat tidak setuju tidak ada. Untuk item 3 responden yang menjawab sangat setuju sebanyak 29 orang, setuju sebanyak 27 orang, ragu-ragu sebanyak 3 orang, tidak setuju sebanyak 1 orang dan tidak ada responden yang menjawab sangat tidak setuju. Untuk item 4 responden yang menjawab sangat setuju sebanyak 10 orang, setuju sebanyak 21 orang, raguragu sebanyak 24 orang dan responden yang menjawab tidak setuju sebanyak 5 orang dan tidak ada responden yang menjawab sangat tidak setuju. Untuk item 5 responden yang menjawab sangat setuju sebanyak 30 orang, setuju sebanyak 22 orang, ragu-ragu sebanyak 8 orang, dan tidak ada responden yang menjawab tidak setuju dan sangat tidak setuju. Untuk item 6 reponden yang menjawab sangat setuju sebanyak 29 orang, setuju sebanyak 26 orang, ragu-ragu sebanyak 5 orang, dan tidak ada responden yang menjawab tidak setuju dan sangat tidak setuju. Untuk item 7 responden yang menjawab sangat setuju sebanyak 29 orang, setuju sebanyak 22 orang, ragu-ragu sebanyak 7 orang, tidak setuju sebanyak 1 orang dan sangat tidak setuju sebanyak 1 orang. Untuk item 8 responden yang menjawab sangat setuju sebanyak 26 orang, setuju sebanyak 25 orang, ragu-ragu sebanyak 5 orang, tidak setuju sebanyak 1 orang dan sangat tidak setuju sebanyak 3 orang. Untuk item 9 responden yang menjawab sangat setuju sebanyak 25 orang, setuju sebanyak 20 orang, ragu-ragu sebanyak 10 orang, tidak setuju sebanyak 3 orang dan sangat tidak setuju sebanyak 2 orang. Untuk item 10 responden yang menjawab sangat setuju sebanyak 43, setuju sebanyak 12 orang, ragu-ragu sebanyak 4 orang, tidak setuju sebanyak 1 orang dan tidak ada responden yang menjawab sangat tidak setuju.

Teknik Analisis Data

Uji Validitas

Tabel 7

Hasil Uji Validitas Variabel Motivasi (X)

\begin{tabular}{|c|c|c|c|}
\hline Item X & r hitung & r table & Kriteria \\
\hline Item 1 & 0,358 & 0,254 & Valid \\
\hline Item 2 & 0,369 & 0,254 & Valid \\
\hline Item 3 & 0,330 & 0,254 & Valid \\
\hline Item 4 & 0,564 & 0,254 & Valid \\
\hline Item 5 & 0,298 & 0,254 & Valid \\
\hline Item 6 & 0,359 & 0,254 & Valid \\
\hline Item 7 & 0,661 & 0,254 & Valid \\
\hline Item 8 & 0,512 & 0,254 & Valid \\
\hline Item 9 & 0,636 & 0,254 & Valid \\
\hline Item 10 & 0,561 & 0,254 & Valid \\
\hline
\end{tabular}

Sumber : Data primer yang diolah, 2017

Dari tabel diatas menunjukkan bahwa semua item yang digunakan untuk mengukur variabel (X) yang digunakan dalam penelitian ini mempunyai koefesien korelasi yang lebih besar dari $r$ tabel. Dari hasil tersebut menunjukkan bahwa semua item yang ada pada variabel (X) tersebut adalah valid dan dapat dikatakan bahwa item-item yan terdapat dikuesioner benar-benar mampu untuk mengungkapkan apa yang akan diteliti. 
Tabel 8

Hasil Uji Validitas Variabel Kinerja Karyawan (Y)

\begin{tabular}{|c|c|c|c|}
\hline Item Y & r hitung & r table & Kriteria \\
\hline Item 1 & 0,466 & 0,254 & Valid \\
\hline Item 2 & 0,472 & 0,254 & Valid \\
\hline Item 3 & 0,359 & 0,254 & Valid \\
\hline Item 4 & 0,257 & 0,254 & Valid \\
\hline Item 5 & 0,462 & 0,254 & Valid \\
\hline Item 6 & 0,387 & 0,254 & Valid \\
\hline Item 7 & 0,607 & 0,254 & Valid \\
\hline Item 8 & 0,585 & 0,254 & Valid \\
\hline Item 9 & 0,545 & 0,254 & Valid \\
\hline Item 10 & 0,507 & 0,254 & \\
\hline
\end{tabular}

Sumber : Data primer yang diolah, 2017

Dari tabel diatas menunjukkan bahwa semua item yang digunakan untuk mengukur variabel (Y) yang digunakan dalam penelitian ini mempunyai koefesien korelasi yang lebih besar dari $r$ tabel. Dari hasil tersebut menunjukkan bahwa semua item yang ada pada variabel (Y) tersebut adalah valid dan dapat dikatakan bahwa item-item yang terdapat dikuesioner benar-benar mampu untuk mengungkapkan apa yang akan diteliti.

Berdasarkan tabel diatas diperoleh informasi mengenai tingkat validitas bahwa seluruh item dinyatakan valid dan dapat digunakan untuk penelitian. Hasil pengujian secara lengkap dapat dilihat pada lampiran rekapitulasi tingkat validitas item pertanyaan instrumen penelitian dapat disajikan pada tabel berikut :

Tabel 9

Rekapitulasi Hasil Uji Item Pertanyaan Instrumen

\begin{tabular}{|c|c|c|c|c|c|c|}
\hline \multirow{2}{*}{ Kuesioner validitas } & \multicolumn{2}{|c|}{ Valid } & \multicolumn{2}{c|}{ Tidak Valid } & \multicolumn{2}{c|}{ Total } \\
\cline { 2 - 7 } & Jumlah & $\mathbf{\%}$ & Jumlah & $\mathbf{\%}$ & Jumlah & \% \\
\hline Motivasi (X) & 10 & 100 & 0 & 0 & 10 & $100 \%$ \\
\hline Kinerja Karyawan (Y) & 10 & 100 & 0 & 0 & 10 & $100 \%$ \\
\hline Jumalh & $\mathbf{2 0}$ & $\mathbf{1 0 0 \%}$ & $\mathbf{0}$ & $\mathbf{0 \%}$ & $\mathbf{2 0}$ & $\mathbf{1 0 0 \%}$ \\
\hline
\end{tabular}

Sumber : Data primer yang dioleh, 2017

Berdasarkan pada data tabel diatas ternyata seluruh item pertanyaan merupakan item yang terpilih dan dapat digunakan sebagai alat pengumpul data (kuesioner).

\section{Uji Reliabilitas}

\section{Tabel 10}

Hasil Uji Reliabilitas

\begin{tabular}{|c|c|c|c|}
\hline Variabel & Alpha Hitung & Parameter Alpha & Kriteria \\
\hline Motivasi $(\mathrm{X})$ & 0,610 & 0,254 & Reliabel \\
\hline Kinerja Karyawan $(\mathrm{Y})$ & 0,616 & 0,254 & Reliabel \\
\hline
\end{tabular}

Sumber : Data primer yang diolah, 2017

Hasil uji reliabilitas tersebut meunjukkan bahwa semua variabel mempunyai koefesien data alpha yang cukup besar yaitu diatas 0,254 sehingga dapat dikatakan semua konsep pengukur masing-masing variabel dari kuesioner adalah reliabel yang berarti bahwa kuesioner yang digunakan dalam penelitian ini merupakan kuesioner yang handal dengan kata lain alat ukur tersebut mempunyai hasil konsisten apabila digunakan berkali-kali pada waktu yang berbeda. 


\section{Hasil Analisis Regresi Linear Sederhana}

\section{Tabel 11}

Hasil Analisis Regresi Linier Sederhana

\begin{tabular}{|cc|c|c|c|c|c|}
\hline \multirow{2}{*}{ Model } & \multicolumn{2}{|c|}{ Unstandardized Coefficients } & $\begin{array}{c}\text { Standardized } \\
\text { Coefficients }\end{array}$ & \multirow{2}{*}{ Sig. } \\
\cline { 3 - 5 } & \multicolumn{2}{|c|}{ B } & Std. Error & Beta & & \\
\hline \multirow{2}{*}{1} & (Constant) & 6,218 & 2,490 & & 2,497 &, 015 \\
& Motivasi &, 851 &, 058 &, 886 & 14,569 &, 000 \\
\hline
\end{tabular}

Sumber : Data primer yang diolah, 2017

Hasil perhitungan pada tabel 4.9 diatas didapat persamaan regresi sebagai berikut :

$$
\begin{array}{ll}
\mathbf{Y}^{\prime} & =\mathbf{a}+\mathbf{b X} \\
\mathbf{Y}^{\prime} & =6,218+\mathbf{0 , 8 5 1 X}
\end{array}
$$

Angka-angka pada tabel 4.9 diatas dapat diartikan sebagai berikut :

- Konstanta sebesar 6,218; artinya jika motivasi (X) nilainya adalah 0, maka kinerja karyawan (Y) nilainya positif yaitu sebesar 6,218.

- Koefesien regresi variabel motivasi (X) sebesar 0,851; artinya jika motivasi mengalami peningkatan 1 maka kinerja karyawan (Y) akan mengalami peningkatan sebesar 0,851 . Begitu juga sebaliknya, jika nilai motivasi mengalami penurunan 1 maka kinerja karyawan akan mengalami penurunan sebesar 0,851. Koefesien bernilai positif artinya terjadi hubungan positif antara motivasi dengan kinerja karyawan, semakin meningkatnya motivasi maka semakin menigkatkan kinerja karyawan.

\section{Hasil Analisis Korelasi Sederhana}

\section{Tabel 12}

\section{Hasil Analisis Korelasi Sederhana}

\begin{tabular}{ll|l|l|} 
Correlations & Kinerja Karyawan & Motivasi \\
\hline \multirow{3}{*}{ Kinerja Karyawan } & Pearson Correlation & 1 &, 886 \\
& Sig. (2-tailed) & 60 &, 000 \\
\multirow{2}{*}{ Motivasi } & $\mathrm{N}$ & 60 \\
& Pearson Correlation &, 886 & 1 \\
& Sig. (2-tailed) &, 000 & \\
& $\mathrm{~N}$ & 60 & 60 \\
\hline
\end{tabular}

${ }^{* *}$. Correlation is significant at the 0.01 level (2-tailed).

Sumber : Sumber data primer yang diolah, 2017

Dari analisis korelasi sederhana (r) didapat korelasi antara motivasi dengan kinerja karyawan adalah 0,886. Hal ini menunjukkan bahwa terjadi hubungan yang sangat kuat antara motivasi dengan kinerja karyawan. Sedangkan arah hubungan adalah positif karena nilai $\mathrm{r}$ positif, berarti semakin tinggi motivasi maka semakin meningkatkan kinerja karyawan.

\section{Hasil Uji Hipotesis}

\section{Uji t}

\section{Tabel 13}

Hasil Analisis Regresi Linier Sederhana

\begin{tabular}{|cc|c|c|c|c|c|}
\hline \multirow{2}{*}{ Model } & \multicolumn{2}{|c|}{ Unstandardized Coefficients } & \multirow{2}{*}{$\begin{array}{c}\text { Standardized } \\
\text { Coefficients }\end{array}$} & \multirow{2}{*}{ Sig. } \\
\cline { 3 - 5 } & (Constant) & 6,218 & Std. Error & Beta & & \\
\hline \multirow{2}{*}{1} & Motivasi &, 851 & 2,490 & & 2,497 &, 015 \\
& \multicolumn{2}{|c|}{, 058} &, 886 & 14,569 &, 000 \\
\hline
\end{tabular}

Desember 2018

JURNAL MANAJEMEN KOMPETEN 
Sumber : Data primer yang diolah, 2017

Dari analisis regresi diatas dapat diketahui nilai t Hitung, langkah-langkah pengujian sebagai berikut :

- Tingkat signifikasi menggunakan signifikasi $5 \%$ atau 0,05 adalah ukuran standar yang sering digunakan dalam penelitian.

- Berdasarkan tabel diperoleh t hitung sebesar 14,569.

- Dengan menggunakan signifikasi 0,05 (uji 2 sisi) dengan derajat kebebasan (df) n$\mathrm{k}-1$ atau $60-1-1=58$ (n adalah jumlah responden dan $\mathrm{k}$ adalah jumlah vaiabel independen). Dengan pengujian 2 sisi hasil yang diperoleh untuk tabel sebesar 2,002 (lihat pada lampiran tabel $\mathrm{t}$ ).

- Kriteria pengujian : Ho diterima jika $t$ hitung $\leq \mathrm{t}$ tabel, Ho ditolak jika $\mathrm{t}$ hitung $>\mathrm{t}$ tabel. Oleh karena nilai $t$ hitung $>\mathrm{t}$ tabel $(14,569>2,002)$ maka Ho ditolak, artinya ada pengaruh secara signifikan antara motivasi dengan kinerja karyawan. Jadi dalam kasus ini dapat disimpulkan bahwa motivasi berpengaruh terhadap kinerja pegawai pada Badan Penanggulangan Bencana Daerah Kabupaten Musi Banyuasin. "Diterima".

\section{SIMPULAN DAN SARAN}

\section{Simpulan}

1. Setelah melakukan uji validitas dan uji reliabilitas dengan menggunakan SPSS validitas variabel motivasi dan kinerja karyawan dinyatakan valid karena nilai $r$ hitung $\geq r$ tabel dan reliabilitas dinyatakan reliabel karena nilai motivasi sebesar 0,610 dan nilai kinerja karyawan 0,616, nilai tersebut lebih besar dari nilai $r$ kritis product moment yaitu 0,254 (lihat pada lampiran tabel $r$ ).

2. Konstanta sebesar 6,218; artinya jika motivasi (X) nilainya adalah 0, maka kinerja karyawan (Y) nilainya positif yaitu sebesar 6,218. Koefesien regresi variabel motivasi (X) sebesar 0,851 ; artinya jika motivasi mengalami peningkatan 1 maka kinerja karyawan (Y) akan mengalami peningkatan sebesar 0,851. Begitu juga sebaliknya, jika nilai motivasi mengalami penurunan 1 maka kinerja karyawan akan mengalami penurunan sebesar 0,851 . Koefesien bernilai positif artinya terjadi hubungan positif antara motivasi dengan kinerja karyawan, semakin meningkatnya motivasi maka semakin menigkatkan kinerja karyawan.

3. Berdasarkan nilai uji t pada tabel Coefficients sebesar 14,569 dengan tingkat signifikasi 0,05 hal ini berarti Ho ditolak karena nilai t hitung lebih besar dari nilai t tabel $(14,569>$ 2,002). Jadi dalam kasus ini dapat disimpulkan bahwa motivasi berpengaruh terhadap kinerja pegawai Badan Penanggulangan Bencana Daerah Kabupaten Musi Banyuasin."Diterima".

\section{Saran}

1. Sehubungan dengan signifikannya pengaruh motivasi terhadap kinerja pegawai, maka hendaknya pihak manajemen kantor memperhatikan motivasi dalam pengambilan kebijakan terutama dalam bidang manajemen sumber daya manusia yang merupakan ujung tombak keberhasilan Badan Penanggulangan Bencana Daearah, maka dengan hasil ini diharapkan pimpinan Badan Penanggulangan Bencana Daerah Kabupaten Musi Banyuasin agar dapat turun langsung memperhatikan dan memotivasi para staf atau pegawainya demi terwujudnya visi dan misi yang di harapkan.

2. Badan Penanggulangan Bencana Daerah Kabupaten Musi Banyuasin diharapkan dapat memperhatikan permasalahan mengenai keserasian suasana kerja dan penempatan pegawai yang tepat sesuai dengan keahliannya masing-masing sehingga pegawai dapat 
meningkatkan kinerja nya lebih baik lagi, dan peran penting bagi para pejabat agar dapat menempatkan staf nya pada keahlian yang memang sesuai dengan keahlian para pegawai agar tercipta suana kerja yang profesional dan kondusif.

3. Dalam penelitian ini data primer di peroleh dari hasil penyebaran kuesioner, dimana semua pekerja terlibat memberikan pendapat mereka dan hasil yang kami dapatkan dari penelitian ini meminta untuk pihak BPBD Kab. Musi Banyuasin agar dapat mensejahterakan para pekerja dalam bentuk penghasilan ataupun dari segi kenyamanan dalam bekerja dan penempatan pejabat struktural yang tepat.

\section{DAFTAR PUSTAKA}

Fathoni, Abdurahat. 2011. Metodelogi Penelitian dan Teknik Penyusunan Skripsi. Jakarta: Rineka Cipta.

Handoko, Martin. 2011. Motivasi Daya Penggerak Tingkah Laku. Yogyakarta: Kanisus.

Hasibuan, Melayu P.2011. Manajemen Sumber Daya Manusia. Jakarta: Bumi Aksara.

Hasibuan, Melayu P.2012. Manajemen Sumber Daya Manusia. Edisi Revisi. Jakarta: Bumi Aksara.

Mangkunegara, Anwar Prabu. 2010. Metode Penelitian Manajemen. Jakarta: PT. Refika Aditama.

Mangkunegara, Anwar Prabu. 2011. Pengaruh Motivasi Kinerja Karyawan. Jakarta: PT. Refika Aditama.

Mangkunegara, Anwar Prabu. 2005. Sumber Daya Manusia Perusahaan. Bandung : PT. Rosda Karya

Mangkunegara, Anwar Prabu. 2009. Evaluasi Kinerja Sumber daya Manusia. Edisi Revisi. Jakarta : PT. Refika Aditama.

McCleland, Winter. 2011. Motivating Economic Achivement. New york : Macmillan Company.

Moekijat, Prosojo. 2011. Manajemen Operasional Perusahaan. PT. Raja Grafindo Persada, Jakarta.

Priyatno, Duwi. 2010. Manajemen Sumber Daya Manusia Untuk Perusahaan. Jakarta : Erlangga.

Rivai, Veitzhal2010.Manajemen Sumber Daya Manusia Untuk Perusahaan. Jakarta: PT. Raja Grafindo Persada.

Sanusi, Anwar. 2011. Metodologi Penelitian Bisnis. Malang: Selemba Empat.

Setyawan, Heru. 2010. Metode Penelitian Bisnis. Http://Zonainfosemua.com. Diakses Tanggal 25 November 2016.

Wahjosumidjo.2011. Faktor Yang Mempengaruhi Motivasi, Jakarta: Ghalia. 